\title{
GMR
}

\section{Multivariate statistics applied to the reaction of common bean plants to parasitism by Meloidogyne javanica}

L.N.S. Santos ${ }^{1}$ P.D.S. Cabral ${ }^{1}$ G.A.R Neves $^{1}$ F.R Alves ${ }^{2}$ M.B. Teixeira F.N. Cunha ${ }^{1}$ and N.F. Silva ${ }^{1}$

${ }^{1}$ Departamento de Agronomia, Instituto Federal Goiano, Campus Rio Verde, Rio Verde, GO, Brasil

2Departamento de Produção Vegetal, Universidade Federal do Espírito Santo, Centro de Ciências Agrárias, Alto Universitário, Guararema, Alegre, ES, Brasil

Corresponding author: L.N.S. Santos

E-mail: leonardo.santos@ifgoiano.edu.br

Genet. Mol. Res. 16 (1): gmr16019420

Received October 7, 2016

Accepted November 16, 2016

Published March 16, 2017

DOI http://dx.doi.org/10.4238/gmr16019420

Copyright $\left({ }^{\circ} 2017\right.$ The Authors. This is an open-access article distributed under the terms of the Creative Commons Attribution ShareAlike (CC BY-SA) 4.0 License.

\begin{abstract}
The availability of common bean cultivars tolerant to Meloidogyne javanica is limited in Brazil. Thus, the present study aimed to evaluate the reactions of 33 common bean genotypes (23 landrace, 8 commercial, 1 susceptible standard and 1 resistant standard) to $M$. javanica, employing multivariate statistics to discriminate the reaction of the genotypes. The experiment was conducted in a greenhouse using a completely randomized design with seven replicates. The seeds were sown in 1-L pots containing autoclaved soil and sand in a 1:1 ratio (v:v). On day 19, after emergence of the seedlings, the plants were treated with inoculum containing 4000 eggs + second-stage juveniles (J2). At 60 days after inoculation, the seedlings were evaluated based on biometric and parasitism-related traits, such as number of galls, final nematode population per root system, reproduction factor, and percent reduction in the reproduction factor of the nematode (\%RRF). The data were subjected to analysis of variance using the F-test. The Mahalanobis
\end{abstract}

Genetics and Molecular Research 16 (1): gmr16019420 
generalized distance was used to obtain the dissimilarity matrix, and the average linkage between groups was used for clustering. The use of multivariate statistics allowed groups to be separated according to the resistance levels of genotypes, as observed in the \%RRF. The landrace genotypes FORT-09, FORT-17, FORT-31, FORT-32, FORT-34 and FORT-36 presented resistance to $M$. javanica; thus, these genotypes can be considered potential sources of resistance.

Key words: Genetic resistance; Landrace genotypes; Phaseolus vulgaris L.; Root-knot nematode

\section{INTRODUCTION}

The common bean (Phaseolus vulgaris L.) has great socioeconomic importance for Brazil because the country is the largest producer and consumer in the world and because this crop generates a large number of jobs, especially in family agriculture (Cabral et al., 2010). According to CONAB (2015), the Brazilian production of common bean reached 3,166,300 tons in the 2014/2015 harvest, with an average productivity of $1038 \mathrm{~kg} / \mathrm{ha}$.

Based on the observation of high heritability and significant gains with selection, Martins et al. (2016) verified genetic variability between common bean elite lines from carioca, mulatinho, and black types and the selection conditions of elite lines.

Despite the high average productivity, several factors can lead to a drop in common bean crop yield, including the occurrence of serious plant health problems (Cândida et al., 2009), such as attacks by plant-parasitic nematodes that cause root galls, especially those of the genus Meloidogyne (Simão et al., 2010; Santos et al., 2012; Fernandes et al., 2013), which can reduce the potential crop yield by up to $90 \%$ (Zaumeyer and Thomas, 1957; Freire and Ferraz, 1977; Agudelo, 1980; Costa et al., 2001; Simão et al., 2005). It is worth noting that regions with a predominance of high temperatures can interfere with plant resistance to parasitism by the nematode (increasing susceptibility) because high temperatures increase plant stress (Campos et al., 2011).

The damage that M. javanica causes to plants, including bean plants, can be explained by the destruction of nutrients when parasitized by these pathogens, by alterations in the absorption and translocation of water and nutrients, by modification or destruction of root tissues, or by decreases in root growth (Hussey and Williamson, 1997). These events result in several responses in parasitized plants (Bird, 1974), many of which are physiological in nature, generally resulting in yellowing and in reduced plant size and consequently culminating in the reduction of productivity (Viaene and Abawi, 1998; Widmer et al., 1999; Castillo et al., 2006; Santos and Souza, 2006).

There are several control strategies for these plant parasites, including the use of chemical nematicides, whose application is increasingly limited due to their high toxicity, high cost and risk of contamination to organisms and the environment (Nunes et al., 2010). Crop rotation is a recommended measure because it inhibits the reproduction of the plantparasitic nematode in the soil. However, the shortage of materials that combine resistance and good agronomic traits, together with the increased use of monocropping, limits the use of this strategy (Fernandes et al., 2013).

Thus, the most practical, inexpensive and efficient control measure is the use of

Genetics and Molecular Research 16 (1): gmr16019420 
resistant and/or tolerant cultivars (Mauro et al., 2004). In this context, one can cite the huge importance of family farmers, who have cultivated their own genotypes (landrace genotypes) for many years by saving seeds for the next crop and repeating this process in a continuous cycle. This process leads to the selection of genotypes adapted to the local agronomic and socioeconomic conditions, culminating in large genetic variability, which may include traits of high agricultural interest, such as resistance to disease and pests (Alves et al., 2011; Cabral et al., 2011; Santos et al., 2012). An ideal genotype should have an average grain yield that is consistently high in all environments (Corrêa et al., 2016).

To develop cultivars, breeders select superior lines of common bean, and one of the fundamental aspects of plant breeding is the knowledge of the genetic divergence between parents to be crossed. To obtain good parents for use in breeding, it is essential to study the genetic divergence (Voysest et al., 1994, Machado et al., 2002; Rodrigues et al., 2002; Emygdio et al., 2003).

According to Voysest et al. (1994), although there has been an increase in the sources of germplasm in Brazil since 1984, levels of genetic diversity remain low, which can be explained by the fact that common cultivars such as Carioca and Cornell are often used as parents in genetic improvement. This genetic similarity between Brazilian cultivars has been confirmed by Machado et al. (2000) and Emygdio et al. (2003).

Considering the above, it is clear that the identification of less divergent parents, such as those that bean farmers have cultivated for decades without imposing genetic improvement, are very useful for current genetic improvement.

According to Vasconcellos et al. (2016), inoculation of UFLA 116 was able to distinguish between at least one treatment for each gene, indicating that all of the PvPGIP genes were differentially expressed and were associated with resistance to white mold, and increased until the third day after inoculation.

Pedrosa et al. (2000) reported sources of resistance to $M$. incognita in the common bean. However, sources of resistance to $M$. javanica are still rare and were only reported in cultivars with moderate resistance, without satisfactorily decreasing the parasite reproduction (Moura and Régis, 1987; Pedrosa et al., 2000; Simão et al., 2010).

Juliatti et al. (2010) evaluated the resistance of several common bean accessions to six populations of Meloidogyne spp. and found that the genotypes Bambuí, Iapar 57 and Iapar 72 have multiple resistance to four nematode populations, indicating the possibility of using these accessions as possible sources of resistance in breeding programs.

In this context, the use of multivariate analysis can be an alternative for separating the genotypes into groups according to their reactions to parasitism by M. javanica, as this method allows for the simultaneous analysis of several traits and thus can increase the accuracy and precision of the study and, consequently, help select genotypes with higher resistance levels. Therefore, the present work aimed to assess, under greenhouse conditions, the reactions of 23 common bean landrace genotypes, eight commercial cultivars, a susceptible standard and a resistant standard to $M$. javanica, employing multivariate statistics to discriminate the reactions of the genotypes.

\section{MATERIAL AND METHODS}

The initial step was to collect common bean genotypes grown for many years by family farmers (materials that had not yet undergone any official breeding process). The

Genetics and Molecular Research 16 (1): gmr16019420 
genotypes were collected in two regions of the state of Espírito Santo, Brazil, South region,

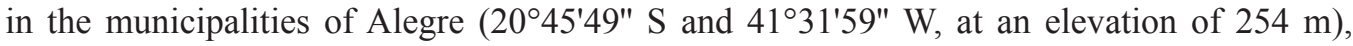
Iconha $\left(20^{\circ} 47^{\prime} 35^{\prime \prime} \mathrm{S}\right.$ and $40^{\circ} 48^{\prime} 40^{\prime \prime} \mathrm{W}$, at an elevation of $\left.8 \mathrm{~m}\right)$, Mimoso do Sul $\left(21^{\circ} 03^{\prime} 51^{\prime \prime} \mathrm{S}\right.$ and $41^{\circ} 21^{\prime} 59^{\prime \prime} \mathrm{W}$, at an elevation of $70 \mathrm{~m}$ ), Muniz Freire (20 $27^{\prime} 51^{\prime \prime} \mathrm{S}$ and $41^{\circ} 24^{\prime} 47^{\prime \prime} \mathrm{W}$, at an elevation of $650 \mathrm{~m}$ ) and Muqui $\left(20^{\circ} 57^{\prime} 06^{\prime \prime} \mathrm{S}\right.$ and $41^{\circ} 20^{\prime} 45^{\prime \prime} \mathrm{W}$, at an elevation of $\left.250 \mathrm{~m}\right)$, and two municipalities in the Serrana region, Marechal Floriano $\left(20^{\circ} 24^{\prime} 46^{\prime \prime} \mathrm{S}\right.$ and $40^{\circ} 40^{\prime} 59^{\prime \prime} \mathrm{W}$, at an elevation of $560 \mathrm{~m})$ and Vargem Alta $\left(20^{\circ} 40^{\prime} 17^{\prime \prime} \mathrm{S}\right.$ and $41^{\circ} 00^{\prime} 25^{\prime \prime} \mathrm{W}$, at an elevation of $650 \mathrm{~m})$.

After the genotypes were collected, the experiment was set up and conducted in a greenhouse in the Center of Agricultural Sciences of the Federal University of Espírito Santo (Centro de Ciências Agrárias da Universidade Federal do Espírito Santo, CCA-UFES). The genotypes evaluated included 23 from the field collections (FORT-02, FORT-03, FORT-05, FORT-06, FORT-07, FORT-08, FORT-09, FORT-11, FORT-12, FORT-13, FORT-14, FORT15, FORT-16, FORT-17, FORT-18, FORT-19, FORT-20, FORT-21, FORT-24, FORT-31, FORT-32, FORT-34 and FORT-36), eight commercial genotypes (Iapar-81, EL-22, Carioca, Serrano, BATT-477, Pérola, FT-Tarumã and Uirapuru) and one susceptible standard (Rico23) (Freire and Ferraz, 1977) and one resistant standard (Aporé) (Ferreira et al., 2010) to $M$. javanica. The experiment was performed once, in a completely randomized design with seven replicates, with each experimental plot consisting of one plant.

The inoculum used was provided by the laboratory of Plant Health Management of the Federal University of Espírito Santo (UFES). For the multiplication of the inoculum, tomato seedlings of the Santa Clara cultivar were grown in a greenhouse using substrate inoculated with $M$. javanica. The substrate used for nematode multiplication was composed of soil and sand at the ratio of $1: 1(\mathrm{v}: \mathrm{v})$ and was autoclaved at $140^{\circ} \mathrm{C}$ for two hours per day for three consecutive days. Next, 5-L pots were filled with the treated substrate and placed in a greenhouse, and two tomato seedlings of the Santa Clara cultivar were subsequently added to each pot.

After 60 days, the tomato roots were separated from the shoots, washed, cut into 0.5$\mathrm{m}$ pieces and ground in a blender using tap water, thus obtaining the inoculum, according to Hussey and Barker (1973) as modified by Boneti and Ferraz (1981). This suspension was used to obtain three 1-mL aliquots, and the eggs were counted under a binocular microscope using a Peter's counting slide.

For the experiment, soil and sand at the ratio of $1: 1(\mathrm{v}: \mathrm{v})$ were used as substrate, as previously described. All crop management practices were conducted according to the recommendations for common bean cultivation by Vieira et al. (2006).

The common bean seeds were germinated on previously sterilized germitest paper and then placed in a germination chamber at a constant temperature of $25^{\circ} \mathrm{C}$ until radicle emergence (Brasil, 2009). Later, two seedlings were transferred to plastic containers containing 1 L substrate.

At day 18, plants were thinned to leave only one plant in each container. The inoculation occurred on day 19 after transplantation (enough time for root growth and development). Thus, each plant received a suspension with 4,000 eggs plus potential juveniles (J2) of $M$. javanica; the suspension was applied in three holes at a depth of approximately 0.3 to $0.4 \mathrm{~m}$, with a distance of approximately 0.3 to $0.4 \mathrm{~m}$ from the plant.

On day 60 after inoculation, the following traits were evaluated: plant height (HEI), number of nodes (NOD), number of trifoliate leaves (TRIL), shoot fresh matter (FM), shoot

Genetics and Molecular Research 16 (1): gmr16019420 
dry matter (DM), root weight (RW), number of pods per plant (NPP), number of seeds per plant (NSP), seed weight per plant (SWP), number of seeds per pod (NSP), hundred-seed weight (W100), visual count of the number of galls (GALL) and the final nematode population, including eggs and juveniles, per root system (FNP). The nematodes were extracted from the root system using the method proposed by Hussey and Barker (1973) as modified by Boneti and Ferraz (1981). In addition, the reproduction factor (RF) of the nematode was calculated through the relationship between the final nematode population $(\mathrm{Pf})$ and the initial nematode population $(\mathrm{Pi})(\mathrm{RF}=\mathrm{Pf} / \mathrm{Pi})$ for each genotype. Then, the percent reduction in the reproduction factor (\%RRF) was calculated according to Oostenbrink (1966), and the host classification adopted was the one proposed by Moura and Régis (1987).

The data were subjected to a Shapiro-Wilk normality test and had a normal distribution, and the homogeneity of the variances was tested using Hartley's test. For the variable percent reduction in the reproduction factor $(\% \mathrm{RRF})$, the data were $\log (\mathrm{x}+1)$-transformed.

The data were then subjected to analysis of variance at a $5 \%$ probability level using the F-test to test for the existence of variability between accessions and to obtain the means and residual variance and covariance matrix, which was used to calculate the dissimilarity matrix between cultivars based on Mahalanobis' generalized distance $\left(D^{2}\right)$. Based on this matrix, clustering was calculated though the mean linkage between groups (UPGMA). The analyses were conducted using the software packages GENES (Cruz, 2013) and R (www.r-project.org).

\section{RESULTS AND DISCUSSION}

According to the results obtained (Table 1), highly resistant (HR) or immune (I) genotypes to the nematode were not identified, as also reported by Moura and Moura (1994), Moura and Régis (1987) and Simão et al. (2010) in studies of common bean resistance to $M$. javanica. However, this work found genotypes classified as resistant. Pedrosa et al. (2000) studied 162 bean genotypes and reported different behaviors regarding resistance to parasitism by $M$. javanica, thus corroborating the results obtained in the present work.

The genotype Rico-23, the susceptible standard, presented the lowest value of \%RRF $(85.43 \%)$ within the moderately resistant (MR) class (Table 1), in agreement with Ferreira et al. (2010), indicating the viability of the M. javanica inoculum. Carneiro and Ferraz (1992) also found the genotype Rico-23 to be susceptible to M. incognita race 3. Santos et al. (2009) evaluated the reactions of common bean genotypes to inoculation of $M$. incognita race 3 and reported that the same genotype behaved as little resistant (LR).

Among the genotypes evaluated (Table 1), eight behaved as resistant (R), among which six were collected genotypes: FORT-09, FORT-17, FORT-31, FORT-32, FORT-34 and FORT-36. This finding demonstrates that these accessions should be evaluated to determine their resistance to biotic and abiotic stresses for application as new sources of resistance in breeding programs. In this sense, Franco et al. (2001) and Bonett et al. (2006) reported the need to characterize local (landrace) common bean genotypes because these variants are adapted to specific regional stress conditions that are not found in commercial crops and therefore likely possess genes of agricultural interest.

The commercial cultivars Uirapuru and Carioca, with reproduction factors (RFs) of 0.11 and 0.82 , respectively, were considered resistant, as shown in Table 1. In a work conducted by Juliatti et al. (2010), the Carioca cultivar was considered susceptible, with an RF of 1.2, very close to the resistance threshold $(>1)$ defined by the methodology used by the authors.

Genetics and Molecular Research 16 (1): gmr16019420 
Table 1. Average values for final nematode population (FNP), reproduction factor (RF), percent reduction in the reproduction factor (\%RRF) and susceptibility reaction of 33 common bean (Phaseolus vulgaris L.) genotypes after at 60 days after inoculation with Meloidogyne javanica.

\begin{tabular}{|c|c|c|c|c|}
\hline Genotypes & FNP & RF & \%RRF & Reaction $^{1}$ \\
\hline Uirapuru & 430.0 & 0.11 & 99.64 & $\mathrm{R}$ \\
\hline FORT-09 & $1,564.3$ & 0.39 & 98.70 & $\mathrm{R}$ \\
\hline FORT-34 & $1,885.7$ & 0.47 & 98.43 & $\mathrm{R}$ \\
\hline FORT-17 & $2,880.0$ & 0.72 & 97.60 & $\mathrm{R}$ \\
\hline FORT-36 & $2,978.6$ & 0.74 & 97.52 & $\mathrm{R}$ \\
\hline FORT-31 & $3,214.3$ & 0.80 & 97.33 & $\mathrm{R}$ \\
\hline Carioca & $3,266.7$ & 0.82 & 97.28 & $\mathrm{R}$ \\
\hline FORT-32 & $4,685.9$ & 1.17 & 96.10 & $\mathrm{R}$ \\
\hline Serrano & $5,280.0$ & 1.32 & 95.61 & MR \\
\hline FORT-19 & $6,533.0$ & 1.63 & 94.56 & MR \\
\hline FORT-24 & $7,199.8$ & 1.80 & 94.01 & MR \\
\hline Pérola & $7,458.5$ & 1.86 & 93.79 & MR \\
\hline Aporé & $8,150.0$ & 2.04 & 93.22 & MR \\
\hline FORT-21 & $8,250.0$ & 2.06 & 93.13 & MR \\
\hline FORT-07 & $8,460.0$ & 2.12 & 92.96 & MR \\
\hline IAPAR-81 & $8,742.9$ & 2.19 & 92.72 & MR \\
\hline FORT-14 & $9,191.7$ & 2.30 & 92.35 & MR \\
\hline BATT-477 & $9,250.0$ & 2.31 & 92.30 & MR \\
\hline FORT-05 & $9,671.4$ & 2.42 & 91.95 & MR \\
\hline FORT-02 & $11,220.0$ & 2.81 & 90.66 & MR \\
\hline FORT-08 & $11,366.7$ & 2.84 & 90.54 & MR \\
\hline FORT-20 & $11,716.7$ & 2.93 & 90.25 & MR \\
\hline FORT-16 & $11,733.5$ & 2.93 & 90.24 & MR \\
\hline FORT-13 & $12,207.1$ & 3.05 & 89.84 & MR \\
\hline FORT-11 & $12,285.7$ & 3.07 & 89.78 & MR \\
\hline FORT-12 & $12,428.6$ & 3.11 & 89.66 & MR \\
\hline FORT-18 & $13,357.3$ & 3.34 & 88.88 & MR \\
\hline FORT-06 & $13,808.3$ & 3.45 & 88.51 & MR \\
\hline FORT-03 & $15,153.1$ & 3.79 & 87.39 & MR \\
\hline FORT-15 & $15,807.3$ & 3.95 & 86.85 & MR \\
\hline EL-22 & $16,242.9$ & 4.06 & 86.48 & MR \\
\hline Rico-23 & $17,510.0$ & 4.38 & 85.43 & MR \\
\hline FT-Tarumã & $120,171.4$ & 30.04 & 0.00 & HS \\
\hline
\end{tabular}

${ }^{1} \mathrm{R}=$ resistant; $\mathrm{MR}=$ moderately resistant; and $\mathrm{HS}=$ highly susceptible.

Twenty-four genotypes showed MR reactions, among which 17 were collected in the field (FORT-02, FORT-03, FORT-05, FORT-06, FORT-07, FORT-08, FORT-11, FORT12, FORT-13, FORT-14, FORT-15, FORT-16, FORT-18, FORT-19, FORT-20, FORT-21 and FORT-24) and five were commercial genotypes (Iapar-81, EL-22, Serrano, BATT-477 and Pérola), in addition to the Aporé (resistant standard) and Rico-23 (susceptible standard) cultivars.

Simão et al. (2005) assessed the behaviors of the cultivars IAPAR-81 and Pérola at various inoculum concentrations and concluded that, despite being good hosts, these cultivars can be considered tolerant to $M$. javanica, similarly to the results obtained in the present study. When evaluating the reactions of common bean genotypes to inoculation with $M$. javanica, Juliatti et al. (2010) classified the Serrano cultivar as resistant, with an RF of 0.7, and the Pérola cultivar as susceptible, with an RF of 1.5. Simão et al. (2010), using an inoculum concentration of 5,000 eggs $\mathrm{mL}^{-1}$ of $M$. javanica and evaluation at 60 days after inoculation, classified the same genotypes as susceptible.

The Aporé cultivar presented a \%RRF value of $93.22 \%$, very close to the resistant class threshold, in which one would expect to find such a genotype. Juliatti et al. (2010) also observed resistance of the Aporé cultivar to the nematode evaluated. According to Table 1, the 
genotype FT-Tarumã was the only highly susceptible cultivar. Silva et al. (2005) studied the reaction of that same genotype to $M$. incognita and classified it as susceptible. Thus, because of its low \%RRF, this genotype should not be planted in areas with Meloidogyne spp. incidence.

Table 2 presents a summary of the analysis of variance and the relative importance of each variable (S.j). Significant differences were observed for 10 variables among the 13 studied, indicating the presence of high genetic variability between the bean accessions evaluated. The variables that were not significant according to the F-test were NOD, GALL and SWP.

Table 2. Summary of the analysis of variance and the relative importance for each variable in the study of genetic diversity, based on Singh (1981), among 33 genotypes of common bean (Phaseolus vulgaris L.) at 60 days after inoculation with Meloidogyne javanica.

\begin{tabular}{l|c|c|c|c}
\hline \multirow{2}{*}{ Parameters } & \multicolumn{2}{|c|}{ Analysis of variance } & \multirow{2}{*}{ S.j } & \multirow{2}{*}{ S.j (\%) } \\
\cline { 2 - 3 } & Q.M. & CV (\%) & 1021.21 & 7.96 \\
\hline HEI & $2814.57^{* *}$ & 33.47 & 196.80 & 1.53 \\
\hline NOD & $91.73^{\text {ns }}$ & 84.68 & 283.07 & 2.21 \\
\hline TRIL & $16.04^{* *}$ & 35.61 & 594.27 & 4.63 \\
\hline FM & $20.23^{* *}$ & 53.04 & 213.32 & 1.66 \\
\hline DM & $0.69^{* *}$ & 42.04 & 66.72 & 7.97 \\
\hline RW & $45.30^{* *}$ & 52.72 & 6156.94 & 0.52 \\
\hline GALL & $0.53^{\text {ns }}$ & 44.91 & 188.61 & 47.99 \\
\hline \%RRF & $0.19^{* *}$ & 7.82 & 198.92 & 1.47 \\
\hline NSP & $2.50^{*}$ & 43.65 & 383.86 & 1.55 \\
\hline SWP & $47.83^{* *}$ & 45.32 & 2168.83 & 2.99 \\
\hline W100 & $1.52^{\text {ns }}$ & 46.14 & 334.21 & \\
\hline NSP & $223.73^{* *}$ & 18.22 & 31.60 & \\
\hline
\end{tabular}

$*, * *$,ns Significant at $5 \%, 1 \%$ and not significant according to the F-test, respectively; CV $(\%)=$ coefficient of variation, \%; S.j = relative contribution of the traits according to Singh's method (1981). HEI = plant height, $\mathrm{cm}$; $\mathrm{NOD}=$ number of nodes; TRIL = number of trifoliate leaves; FM = shoot fresh matter, $\mathrm{g} ; \mathrm{DM}=$ shoot dry matter, $\mathrm{g} ; \mathrm{RW}=$ root weight, $\mathrm{g} ; \mathrm{GALL}=$ visual count of the number of galls; $\% \mathrm{RRF}=$ percent reduction in the reproduction factor, $\%$; NPP = number of pods per plant; NSP = number of seeds per plant; SWP = seed weight per plant, g; $\mathrm{W} 100=$ hundred-seed weight, $\mathrm{g}$; NSP $=$ number of seeds per pod.

When analyzing the relative importance of each variable, S.j (\%), the traits that contributed the most to the genetic distance were \%RRF, W100, RW and HEI, with contributions of $47.99,16.90,7.97$, and $7.96 \%$, respectively. The sum of these traits contributed to $80.82 \%$ of the total variance. Similar results were obtained by Coelho et al. (2007) in experiments with common bean; the authors concluded that the most important variable in the separation of accessions was the hundred-seed weight.

When analyzing the traits GALL $(0.52 \%)$, NPP (1.47\%), NOD (1.53\%), NSP $(1.55 \%)$ and DM (1.66\%), which have less relative importance for genetic distance (Table 2), no variations were observed for the averages of these traits between genotypes, confirming the ANOVA results, in which GALL and NOD were not significant. Based on these values and according to Singh (1981), the traits NPP, NSP and DM were considered of less importance for genetic divergence.

Cruz and Carneiro (2006) claimed that multicollinearity analysis was important for the study of genetic diversity. Montgomery and Peck (1981) reported that the effect of multicollinearity at moderate to severe levels can cause harmful or absurd results in the analysis of the data, rendering them largely unreliable. However, the level of multicollinearity identified was weak to moderate and, thus, did not hinder the reliability of the data.

Genetics and Molecular Research 16 (1): gmr16019420 
The cophenetic correlation coefficient (CCC) is a measure of agreement between the original dissimilarity values and those represented by the dendrogram; thus, the greater the CCC, the lower the distortion of the clustering (Cruz and Carneiro, 2006). The CCC obtained was 0.985 , demonstrating a high agreement between the cophenetic matrix and the dissimilarity matrix based on the Mahalanobis generalized distance, indicating high reliability of the clustering (Figure 1).

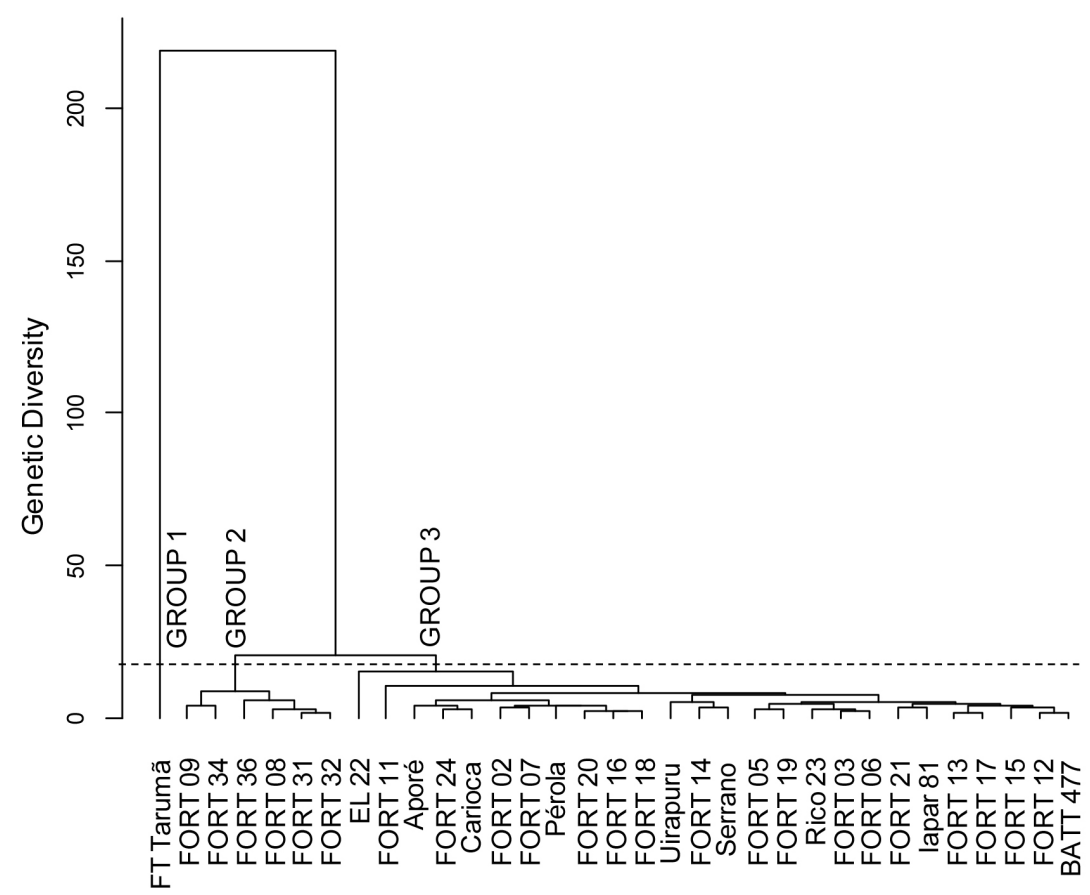

Figure 1. Dissimilarity dendrogram, established by the average linkage method (UPGMA), based on the Mahalanobis distance $\left(\mathrm{D}^{2}\right)$, for 33 genotypes of common bean (Phaseolus vulgaris $\mathrm{L}$.).

The clustering criterion adopted by the UPGMA method (Figure 1) first establishes the formation of a group of similar genotypes, while the distance between the other groups is calculated relative to the formed groups (Cruz and Carneiro, 2006). Therefore, the genotypes clustered in a single group are the most similar morphologically. In this study, the genotypes FORT-13 and FORT-17 were the most similar. It is worth noting that this similarity was not observed in the classification of the susceptibility reaction (Table 1) because there is a difference between the calculation of \%RRF (Moura and Régis, 1987) and the divergence analysis (average of replicates), especially for FORT-17, for which the \%RRF values were $97.60 \%$ for the susceptibility classification and $95.66 \%$ for the distance (Tables 1 and 3 , respectively). In contrast, the average W100, RW and HEI, which together had a $32.83 \%$ contribution for the separation of the genotypes (Table 1), were quite similar between genotypes FORT-13 and FORT-17, as demonstrated in Table 3, thus justifying the high similarity between the genotypes as observed in the dendrogram.

Genetics and Molecular Research 16 (1): gmr16019420 
Table 3. Arithmetic means of traits that contributed the most to the study of genetic diversity among 33 genotypes of common bean (Phaseolus vulgaris L.) at 60 days after inoculation with Meloidogyne javanica.

\begin{tabular}{|c|c|c|c|c|}
\hline \multirow[t]{2}{*}{ Genotypes } & \multicolumn{4}{|c|}{ Arithmetic means } \\
\hline & \%RRF ${ }^{1}$ & $\mathrm{~W} 100^{2}$ & $\mathrm{RW}^{3}$ & $\mathrm{HEI}^{4}$ \\
\hline Uirapuru & 99.62 & 18.86 & 2.31 & 53.86 \\
\hline FORT-09 & 98.61 & 38.11 & 2.34 & 33.90 \\
\hline FORT-34 & 98.33 & 44.53 & 2.02 & 37.02 \\
\hline FORT-36 & 97.36 & 34.09 & 3.81 & 52.39 \\
\hline FORT-31 & 97.15 & 30.85 & 1.97 & 39.33 \\
\hline Carioca & 97.10 & 24.48 & 4.19 & 97.77 \\
\hline FORT-32 & 95.85 & 30.77 & 1.59 & 31.97 \\
\hline FORT-17 & 95.66 & 23.27 & 6.27 & 70.20 \\
\hline Serrano & 95.32 & 20.31 & 5.12 & 55.49 \\
\hline FORT-19 & 94.21 & 20.07 & 2.41 & 52.22 \\
\hline FORT-24 & 93.62 & 23.54 & 3.83 & 88.90 \\
\hline Pérola & 93.39 & 27.64 & 4.26 & 109.31 \\
\hline Aporé & 92.78 & 23.28 & 4.00 & 89.36 \\
\hline FORT-21 & 92.69 & 25.23 & 2.41 & 50.26 \\
\hline Iapar-81 & 92.25 & 27.47 & 5.65 & 61.40 \\
\hline FORT-14 & 91.85 & 20.61 & 6.04 & 73.39 \\
\hline BATT-477 & 91.80 & 25.64 & 4.05 & 61.63 \\
\hline FORT-05 & 91.43 & 22.38 & 4.21 & 59.31 \\
\hline FORT-02 & 90.05 & 30.98 & 5.23 & 74.86 \\
\hline FORT-07 & 89.93 & 28.01 & 4.27 & 86.45 \\
\hline FORT-08 & 89.92 & 31.00 & 2.83 & 32.20 \\
\hline FORT-20 & 89.61 & 24.47 & 4.30 & 94.30 \\
\hline FORT-16 & 89.60 & 26.46 & 6.12 & 87.89 \\
\hline FORT-13 & 89.18 & 24.57 & 5.85 & 72.47 \\
\hline FORT-11 & 89.11 & 21.60 & 4.02 & 76.01 \\
\hline FORT-12 & 88.98 & 27.01 & 6.44 & 77.89 \\
\hline FORT-18 & 88.16 & 24.71 & 6.45 & 84.23 \\
\hline FORT-06 & 87.76 & 21.79 & 5.10 & 77.26 \\
\hline FORT-03 & 86.57 & 22.95 & 5.62 & 59.17 \\
\hline FORT-15 & 85.99 & 24.94 & 5.77 & 67.09 \\
\hline EL-22 & 85.6 & 22.02 & 7.18 & 46.12 \\
\hline Rico-23 & 84.48 & 19.11 & 4.20 & 60.84 \\
\hline FT-Tarumã & 0.00 & 18.12 & 16.10 & 64.59 \\
\hline
\end{tabular}

A cutoff was applied at $17.83(8.19 \%)$ to better analyze the groups formed (Figure 1). Thus, three major groups were formed (G1, G2 and G3), with only small changes relative to the classification in Table 1. The genotypes FORT-08, FORT-09, FORT-31, FORT-32, FORT34 and FORT-36 were placed in G2. When using the classification proposed by Moura and Régis (1987), all five of these genotypes were classified as resistant (Table 1), and only FORT08 was classified as moderately resistant. Therefore, the formation of G2 was more influenced by W100 than by $\% \mathrm{RRF}$, as all six genotypes had average W100 values above $30.77 \mathrm{~g}$. This grouping becomes more evident when analyzing the Carioca and Uirapuru genotypes, which were also classified as resistant (Table 1) and were placed in G1, as they had W100 values lower than G2, as shown in Table 3.

The largest genetic divergence occurred between genotypes FT-Tarumã and FORT20. The FT-Tarumã differed significantly from the other genotypes studied and formed group G3 alone (Figure 1). This finding is explained by fact that the average \%RRF, the variable that most contributed to the calculation of the distance, had a value of zero (Table 3). This greater divergence agrees with the susceptibility reactions of the genotypes (Table 1), among which FT-Tarumã was the only genotype classified as HS and FORT-20 was the only genotype classified as MR.

Genetics and Molecular Research 16 (1): gmr16019420 
In Figure 1, it can be observed that the Aporé cultivar (resistant standard) was clustered with two other genotypes, the collected genotype FORT-24 and the commercial genotype Carioca, with Aporé and FORT-24 being classified as MR and Carioca as R (Table 1). Table 3 shows that the means of these three genotypes are very close for the four variables that most contributed to the genetic divergence (\%RRF, W100, HEI and RW). This result can explain why they were very close in the clustering analysis, despite the difference in the classification of the susceptibility reaction (Table 1). The genotype Rico-23 (susceptible standard) was clustered with the collected genotypes FORT-03 and FORT-06, and these three genotypes were classified as MR based on the Moura and Régis (1987) criteria.

The commercial genotypes evaluated showed strong similarity, as indicated by their clustering into a single large group, G1 (Figure 1). Some examples of this similarity include the percentages of divergence between the cultivars Serrano and Uirapuru $(1.72 \%)$ and between Carioca and Aporé (2.02\%), once again demonstrating the low genetic variability among commercial cultivars. These results are in agreement with the work of Rodrigues et al. (2002), who reported that the cultivars developed in the study have high degrees of similarity. They also confirm the results obtained by Cabral et al. (2010), who evaluated the diversity of bean genotypes through quantitative, qualitative and molecular traits and reported low genetic divergence among the commercial cultivars. These findings also confirm the results by Emygdio et al. (2003), who, working with RAPD (random amplification of polymorphic DNA) molecular markers, concluded that the commercial bean cultivars in Rio Grande do Sul had high degrees of similarity.

Overall, the genotypes collected were distributed in the two groups delineated by multivariate analysis (G1 and G2), demonstrating that they have a wider genetic base than the commercial materials tested. These results were confirmed by Cabral et al. (2011), who evaluated the genetic diversity of commercial and collected genotypes in the South of Espírito Santo. Still, based on the criteria of Moura and Régis (1987), it can be stated that the collected genotypes FORT-09, FORT-17, FORT-31, FORT-32, FORT-34 and FORT-36 have potential for use in breeding programs, as they presented resistance to $M$. javanica. However, additional studies under other soil and weather conditions are needed to confirm the results obtained.

\section{CONCLUSION}

Multivariate statistics were efficient in separating the genotypes into different groups according to their reactions to parasitism by M. javanica.

The landrace genotypes FORT-09, FORT-17, FORT-31, FORT-32, FORT-34 and FORT-36 presented resistance to the root-knot nematode $M$. javanica.

\section{REFERENCES}

Agudelo FV (1980). Nematodes. In: Bean production problems: disease insect, soil and climatic constraints of Phaseolus vulgaris (Schwartz HF and Galvez GE, eds.). Centro Internacional de Agricultura Tropical, Cali/Colombia, 315-326.

Alves FR, Santos LNS, Moraes WB, Cosmi FC, et al. (2011). Reaction of common bean genotypes to Meloidogyne incognita Race 1. Idesia 29: 95-98. http://dx.doi.org/10.4067/S0718-34292011000200012

Bird AF (1974). Plant response to root-knot nematode. Annu. Rev. Phytopathol. 12: 69-85. http://dx.doi.org/10.1146/ annurev.py.12.090174.000441

Boneti JIS and Ferraz S (1981). Modificação do método de Hussey and Barker para extração de ovos de Meloidogyne exigua de raízes de cafeeiro. Fitopatol. Bras. 6: 553.

Genetics and Molecular Research 16 (1): gmr16019420 
Bonett LP, Gonçalves-Vidigal MC, Schuelter AR, Vidigal Filho PS, et al. (2006). Genetic divergence in germplasm of common bean in Paraná State, Brazil. Semin. Cienc. Agrar. 27: 547-560. http://dx.doi.org/10.5433/1679$\underline{0359.2006 \mathrm{v} 27 \mathrm{n} 4 \mathrm{p} 547}$

Brasil (2009). Regras para análise de sementes. Ministério da Agricultura, Pecuária e Abastecimento, Secretaria de Defesa Agropecuária, Brasília/Brasil.

Cabral PDS, Soares TCB, Gonçalves LSA, Amaral Júnior AT, et al. (2010). Quantification of the diversity among common bean accessions using Ward-MLM strategy. Pesqui. Agropecu. Bras. 45: 1124-1132. http://dx.doi.org/10.1590/ $\underline{\text { S0100-204X2010001000011 }}$

Cabral PDS, Soares TCB, Lima ABP, de Miranda FD, et al. (2011). Genetic diversity in local and commercial dry bean (Phaseolus vulgaris) accessions based on microsatellite markers. Genet. Mol. Res. 10: 140-149.http://dx.doi. org/10.4238/vol10-1gmr993

Campos HD, Silva JRC, Campos VP, Silva LHCP, et al. (2011). Effect of soil temperature on infectivity and reprodution of Meloidogyne javanica and Heterodera glycines in soybean cultivars. Cienc. Agrotec. 35: 900-907. http://dx.doi. org $/ 10.1590 / \mathrm{S} 1413-70542011000500006$

Cândida DV, Costa JGC, Rava CA and Carneiro MS (2009). Genetic control of Fusarium wilt in common bean. Trop. Plant Pathol. 34: 379-384.

Carneiro RG and Ferraz S (1992). Bean cultivars reation to Meloidogyne incognita race 3. Nemat. Bras. 16: 35-40.

Castillo P, Landa BB and Navas-Cortés JA (2006). First Report of Meloidogyne arenaria Parasitizing Lettuce in Southern Spain. Plant Dis. 90: 975. http://dx.doi.org/10.1094/PD-90-0975A

Coelho CMM, Coimbra JLM, Souza CA, Altamir B, et al. (2007). Genetic diversity in common bean accessions. Cienc. Rural 37: 1241-1247. http://dx.doi.org/10.1590/S0103-84782007000500004

CONAB (2015). Acompanhamento de safra brasileira de grãos, Safra 2014/15, nono levantamento. CONAB, Brasília/Brasil.

Corrêa AM, Teodoro PE, Gonçalves MC, Santos A, et al. (2016). Selection of common bean (Phaseolus vulgaris L.) genotypes using a genotype plus genotype x environment interaction biplot. Genet. Mol. Res. 15: 1-9.http://dx.doi. org $/ 10.4238 / \mathrm{gmr} .15038427$

Costa MJN, Oliveira S, Coelho SJ and Campos VP (2001). Nematodes in ornamental plant roots. Cienc. Agrotec. 25: $1127-1132$.

Cruz CD (2013). GENES - A software package for analysis in experimental statistics and quantitative genetics. Acta Sci. Agron. 35: 271-276. http://dx.doi.org/10.4025/actasciagron.v35i3.21251

Cruz CD and Carneiro PCS (2006). Modelos Biométricos aplicados ao Melhoramento Genético. 2nd edn. Universidade Federal de Viçosa, Viçosa/MG.

Emygdio BM, Antunes IF, Nedel JL and Choer E (2003). Genetic diversity in cultivars and landraces of common bean based on RAPD markers analysis. Pesqui. Agropecu. Bras. 38: 1165-1171. http://dx.doi.org/10.1590/S0100204X2003001000005

Fernandes RH, Lopes EA, Vieira BS and Bontempo AF (2013). Control of Meloidogyne javanica on common beans with Bacillus spp. isolates. R. Tróp. Ci. Agr. Biol. 7: 76-81.

Ferreira S, Gomes LAA and Maluf WR (2010). Resistance of Dry Bean and Snap Bean Cultivars to Root-knot Nematodes. HortScience 45: 320-322.

Franco MC, Cassini STA, Oliveira VR and Tsai SM (2001). Characterization of the genetic diversity of common beans by RAPD markers. Pesqui. Agropecu. Bras. 36: 381-385. http://dx.doi.org/10.1590/S0100-204X2001000200023

Freire FCO and Ferraz S (1977). Nematóides associados ao feijoeiro, na Zona da Mata, Minas Gerais, e efeitos do parasitismo de Meloidogyne incognita e M. javanica sobre o cultivar "Rico 23". Rev. Ceres 24: 141-149.

Hussey RS and Williamson VM (1997). Physiological and molecular aspects of nematode parasitism. In: Plant and Nematode Interactions (Barker KR, Pederson GA, Windham GL, eds.). American Society of Agronomy. Madison, WI.

Juliatti FC, Walber R, Santos MA and Sagata E (2010). Reation of resistance in common bean to root-knot nematodes. Biosci. J. 26: 763-769.

Machado CF, Santos JB and Nunes GHS (2000). Escolha de genitores de feijoeiro por meio da divergência avaliada a partir de caracteres morfo-agronômicos. Bragantia 59: 11-20. http://dx.doi.org/10.1590/S0006-87052000000100004

Machado CF, Nunes GHS, Ferreira DF and Santos JB (2002). Genetic divergence among genotypes of common bean through of multivariates techniques. Cienc. Rural 32: 251-258.

Martins SM, Melo PGS, Faria LC, Souza TLPO, et al. (2016). Genetic parameters and breeding strategies for high levels of iron and zinc in Phaseolus vulgaris L. Genet. Mol. Res. 15: 1-14.http://dx.doi.org/10.4238/gmr.15028011

Mauro AO, Unêda-Trevisoli SH, Mauro SMZ, Costa MM, et al. (2004). Efficiency of microsatellite markers in assisted selection for resistance to soybean cyst nematode (race 3). Crop Breed. Appl. Biotechnol. 4: 28-34. http://dx.doi. org/10.12702/1984-7033.v04n01a05

Genetics and Molecular Research 16 (1): gmr16019420 
Montgomery DC and Peck EA (1981). Introduction to linear regression analysis. 1st edn. Wiley, New York.

Moura AM and Moura RM (1994). Reactions of Phaseolus vulgaris genotypes in relation to Meloidogyne incognita Raça 1 and M. javanica. Nemat. Bras. 18: 50-56.

Moura RM and Régis EMO (1987). Reactions of common bean cultivares (Phaseolus vulgaris) in relation to parasitism of Meloidogyne javanica and M. incognita (nematoda: heteroderidae). Nemat. Bras. 11: 215-225.

Nunes HT, Monteiro AC and Pomela AWV (2010). Use of microbial and chemical agents to control Meloidogyne incognita in soybean. Acta Sci. Agron. 32: 403-409.

Oostenbrink M (1966). Major characteristics of the relation between nematodes and plants. Meded. Landbouwhogeschool 66: 3-46.

Pedrosa EMR, Moura RM and Silva EG (2000). Respostas de genótipos de Phaseolus vulgaris à meloidoginoses e alguns mecanismos envolvidos na reação. Fitopatol. Bras. 25: 190-196.

Rodrigues LS, Antunes IF, Teixeira MG and Silva JB (2002). Divergência genética entre cultivares locais e cultivares melhoradas de feijão. Pesqui. Agropecu. Bras. 37: 1275-1284. http://dx.doi.org/10.1590/S0100-204X2002000900011

Santos HS and Souza RJ (1996). Efeito de métodos de plantio e manejo do solo infestado com Meloidogyne javanica na produção de alface sob estufa plástica. Hortic. Bras. 14: 19-22.

Santos LNS, Cabral PDS, Matta FP, Alves FR, et al. (2009). Behavior of genotypes of beans to Meloidogyne incognita race 3. Rev. Bras. de Agroecologia 4: 909-912.

Santos LNS, Alves FR, Belan LL, Cabral PDS, et al. (2012). Damage quantification and reaction of bean genotypes (Phaseolus vulgaris L.) to Meloidogyne incognita race 3 and M. javanica. Summa Phytopathol. 38: 24-29.

Silva FB, Ramalho MAP and Abreu AFB (2005). Genetic control of Meloidogyne incognita resistance in common bean. Bean Improvement Cooperative 48: 64-65.

Simão G, Homechin M, Santiago DC, Silva RTV, et al. (2005). Behavior of two common bean cultivars in relation to Meloidogyne javanica. Cienc. Rural 35: 266-270.

Simão G, Orsini IP, Sumida CH, Homechin M, et al. (2010). Reaction of cultivars and lines of bean in relation to Meloidogyne javanica and Fusarium oxysporum f. sp. Phaseoli. Cienc. Rural 40: 1003-1008. http://dx.doi. org/10.1590/S0103-84782010000500001

Singh SP (1981). The relative importance of characters affecting genetic divergence. Indian J. Genet. Plant Breed. 41: 237-245.

Vasconcellos RCC, Lima TFC, Fernandes-Brum CN, Chalfun-Junior A, et al. (2016). Expression and validation of PvPGIP genes for resistance to white mold (Sclerotinia sclerotiorum) in common beans (Phaseolus vulgaris L.). Genet. Mol. Res. 15: 1-11.http://dx.doi.org/10.4238/gmr.15038269

Viaene NM and Abawi GS (1998). Management of Meloidogyne hapla on lettuce in organic soil with sudangrass as a cover crop. Plant Dis. 82: 945-952. http://dx.doi.org/10.1094/PDIS.1998.82.8.945

Vieira C, Paula Júnior TJ and Borém A (2006). Feijão: Aspectos gerais e cultura no Estado de Minas. 2nd edn. Universidade Federal de Viçosa, Viçosa/MG.

Voysest O, Valencia MC and Amezquita MC (1994). Genetic diversity among Latin American Andean and Mesoamerican common bean cultivars. Crop Sci. 34: 1100-1110. http://dx.doi.org/10.2135/cropsci1994.0011183X003400040049x

Widmer TL, Ludwig JW and Abawi GS (1999). The northern root-knot nematode on carrot, lettuce, and onion in New York. New York's food and life sciences bulletin. New York. N156.

Zaumeyer WJ and Thomas HR (1957). A monographic study of bean diseases and methods for their control. United States department of agriculture, Washington DC.

Genetics and Molecular Research 16 (1): gmr16019420 